\title{
Characterization of a Potyvirus Infecting Sunflower in Argentina
}

G. Dujovny, T. Usugi, and K. Shohara, Instituto de Fitopatología y Fisiología Vegetal (IFFIVE-INTA), Cno. 60 Cuadras Km 5 1/2, 5119 Córdoba, Argentina, and S. Lenardon, IFFIVE-INTA and Facultad de Agronomía y Veterinaria, Universidad Nacional de Río Cuarto, 5800 Río Cuarto, Córdoba, Argentina

\begin{abstract}
Dujovny, G., Usugi, T., Shohara, K., and Lenardon, S. 1998. Characterization of a potyvirus infecting sunflower in Argentina. Plant Dis. 82:470-474.

A virus causing chlorotic mottling symptoms on sunflower was found in various locations in Argentina. Symptoms were small chlorotic spots, yellow blotches on leaves, and plant stunting. Virus transmission efficiency by mechanical inoculation was 73 to $100 \%$, and by Myzus persicae was 31 to $49 \%$. The host range included members of the Amaranthaceae, Asteraceae, Chenopodiaceae, and Solanaceae families. Electron microscopy of leaf dips from infected plants revealed flexuous particles $17 \mathrm{~nm}$ wide and $770 \mathrm{~nm}$ long. Cytoplasmic laminar aggregates and pinwheel inclusions were observed in ultrathin sections. Purified virus preparations analyzed by sodium dodecyl sulfate-polyacrylamide gel electrophoresis resolved a capsid protein of $33 \mathrm{kDa}$. A monoclonal antibody to aphid-transmitted potyviruses reacted with the capsid protein of this virus. In dot blot immunoassays, a polyclonal antiserum (early bleeding) reacted with infected sunflowers and weakly with Bidens mottle potyvirus, but not with either maize dwarf mosaic potyvirus or potato virus $\mathrm{Y}$. The evidence suggests that a potyvirus is infecting sunflower, and a partial characterization of the causal agent is reported.
\end{abstract}

Several potyviruses infect sunflower (Helianthus annuus L.). Arnott and Smith (1) reported potyvirus-like particles in wild sunflowers and described several histopathological changes in mesophyll cells. Sunflowers became infected after rub-inoculation with Bidens mottle potyvirus (BiMoV) and Bidens mosaic virus (BiMV), a possible potyvirus member $(2,5,6,13)$. Also, BiMV was reported in commercial sunflower fields in the states of São Paulo, Minas Gerais, and Paraná in Brazil (3).

In Argentina, viruslike symptoms in sunflower have been associated with potyvirus-like particles (R. Delhey, unpublished, and J. Muñoz, unpublished). In the province of Entre Ríos, potyvirus-like particles were detected in symptomatic sunflowers in 1992 to 1993 (N. Formento, unpublished). A survey in the same geographic area during 1993 revealed chlorotic mottling, mild mosaic, and ring spot symptoms in commercial sunflower plots (8). Since then, chlorotic mottling symptoms have been frequently observed in commercial sunflower fields in Paraná (Entre Ríos) and Venado Tuerto (Santa Fé), and in wild sunflowers (Helianthus petiolaris L.) in Río Cuarto (Córdoba) (S. Lenardon, unpublished). The disease produces remarkable symptoms, especially in

Corresponding author: Sergio Lenardon

E-mail: lenardon@satlink.com

Accepted for publication 7 January 1998.

Publication no. D-1998-0303-01R

(C) 1998 The American Phytopathological Society young plants, but the causal virus had not been characterized. This study describes biological properties of the virus, a purification protocol, the molecular weight of the capsid protein, and serological relations of this sunflower virus (SuV) from Argentina.

\section{MATERIALS AND METHODS}

Inoculum source. Sunflower leaves showing chlorotic mottling were collected from fields in Paraná (Entre Rios). A single chlorotic lesion from one of these leaves was cut out and ground in a mortar with $0.01 \mathrm{M}$ phosphate buffer, $\mathrm{pH}$ 7.2, containing $1 \%$ (wt/vol) $\mathrm{Na}_{2} \mathrm{SO}_{3}$ and 600 mesh silicon carbide $(1: 5, \mathrm{wt} / \mathrm{vol})$. The resulting slurry was used to inoculate Chenopodium quinoa Willd. plants, which were kept in the greenhouse at $22^{\circ} \mathrm{C} \pm 5^{\circ} \mathrm{C}$ and developed local lesions. A single lesion was used to inoculate a healthy sunflower plant, and from it, to initiate and maintain the virus source on sunflowers and Nicotiana occidentalis $\mathrm{L}$.

Host range. Rub-inoculations were made to 42 species belonging to 10 plant families: Arachis hypogaea L., Beta vulgaris L., Bidens subalternans D.C., Brassica napus L., B. oleracea L., Callistephus chinensis (L.) Nees, Capsicum annuum L., Catharanthus roseus (L.) G. Don, Cicer arietinum L., Cichorium intybus L., Chenopodium amaranticolor Costa \& Reyn., C. quinoa Wild., Chrysanthemum coronarium L., Cucumis sativus L., Cucurbita maxima Duchesne, $C$. pepo L., Datura metel L., D. stramonium L., Glycine max (L.) Merr., Gomphrena globosa L., Gossypium barbadense L., Helianthus annuus, Lactuca sativa L., Lathyrus odoratus L., Lens culinaris Medik., Lycopersicon esculentum Mill., Nicotiana clevelandii L., $N$. glutinosa L., N. occidentalis, $N$. rustica L., N. tabacum L. cv. Samsun and cv. Xanthi, Pisum sativum L., Phaseolus vulgaris L., Physalis floridana L., Tagetes erecta L., Vicia faba L., Vigna sinensis (L.) Endl., Wedelia buphthalmiflora Jack., Sorghum bicolor (L.) Moench, Zinnia elegans Jacq., and Zea mays L.

Aphid transmission. Vector transmission experiments were carried out using adult Myzus persicae Sulzer, which were starved for $3 \mathrm{~h}$ prior to a 1-min acquisition access period on infected and healthy sunflower plants. Then, a single aphid was placed on healthy sunflower seedlings for a
Table 1. Plant species artificially infected with sunflower virus

\begin{tabular}{|c|c|c|}
\hline Plant species & Infection $(\%)^{\mathbf{a}}$ & Symptoms $^{\text {b }}$ \\
\hline $\begin{array}{l}\text { Amaranthaceae } \\
\text { Gomphrena globosa L. }\end{array}$ & 80 & cl. mo. \\
\hline $\begin{array}{l}\text { Asteraceae } \\
\text { Bidens subalternans } \text { D.C. } \\
\text { Chrysanthemum coronarium L. } \\
\text { Helianthus annuus L. } \\
\text { Tagetes erecta L. } \\
\text { Zinnia elegans Jacq. }\end{array}$ & $\begin{array}{l}40 \\
60 \\
82 \\
60 \\
80\end{array}$ & $\begin{array}{c}\text { cl. mo. } \\
\text { cl. mo. } \\
\text { cl. mo. } \\
\text { cl. mo. } \\
\text { m. }\end{array}$ \\
\hline $\begin{array}{l}\text { Chenopodiaceae } \\
\text { Chenopodium amaranticolor Costa \& Reyn. } \\
\text { Chenopodium quinoa Wild. }\end{array}$ & $\begin{array}{l}80 \\
65\end{array}$ & $\begin{array}{l}11 . \\
11 .\end{array}$ \\
\hline $\begin{array}{l}\text { Solanaceae } \\
\text { Datura metel } \mathrm{L} . \\
\text { Nicotiana occidentalis } \mathrm{L} .\end{array}$ & $\begin{array}{l}60 \\
88\end{array}$ & $\begin{array}{l}\text { cl. mo. } \\
\text { cl. mo. }\end{array}$ \\
\hline
\end{tabular}

${ }^{a}$ Based on 10 plants, the maximum score obtained in at least three independent repetitions of the trial.

${ }^{\mathrm{b}} \mathrm{cl} . \mathrm{mo} .=$ chlorotic mottling, $\mathrm{m} .=$ mosaic, and $11 .=$ local lesions. 
24-h inoculation access period. Inoculated plants were kept in an insect-free greenhouse; tests were performed four times, with a total of 300 insects.

Seed transmission. Four hundred six plants obtained from seeds of greenhouseinfected sunflower plants were observed for 2 months for symptom development.

Electron microscopy. Infected sunflower leaves were cut into $1 \times 1 \mathrm{~mm}$ pieces and soaked for $5 \mathrm{~min}$ in a drop of $10 \%$ neutralized paraformaldehyde. Grids (600 mesh) coated with collodion film were laid on the drop for $1 \mathrm{~min}$, stained with $2 \%$ potassium phosphotungstate, $\mathrm{pH}$
7, and dried at room temperature. Ultrathin sections of infected tissue also were prepared (10) and examined for cytoplasmic inclusions with a JEOL 1200 EX electron microscope.

Virus purification. $N$. occidentalisinfected leaves were harvested 14 to 21 days after inoculation. Fresh tissue was ground with 4 volumes of $0.5 \mathrm{M}$ borate buffer, $\mathrm{pH} 8$, containing 0.01 M EDTA and $0.1 \%$ thioglicolic acid (extraction buffer). The homogenate was filtered through double cheesecloth, agitated with $10 \%$ chloroform ( $\mathrm{vol} / \mathrm{vol}$ ) for $10 \mathrm{~min}$, and centrifuged with a Beckman JA-14 rotor at 7,000 $\times g$
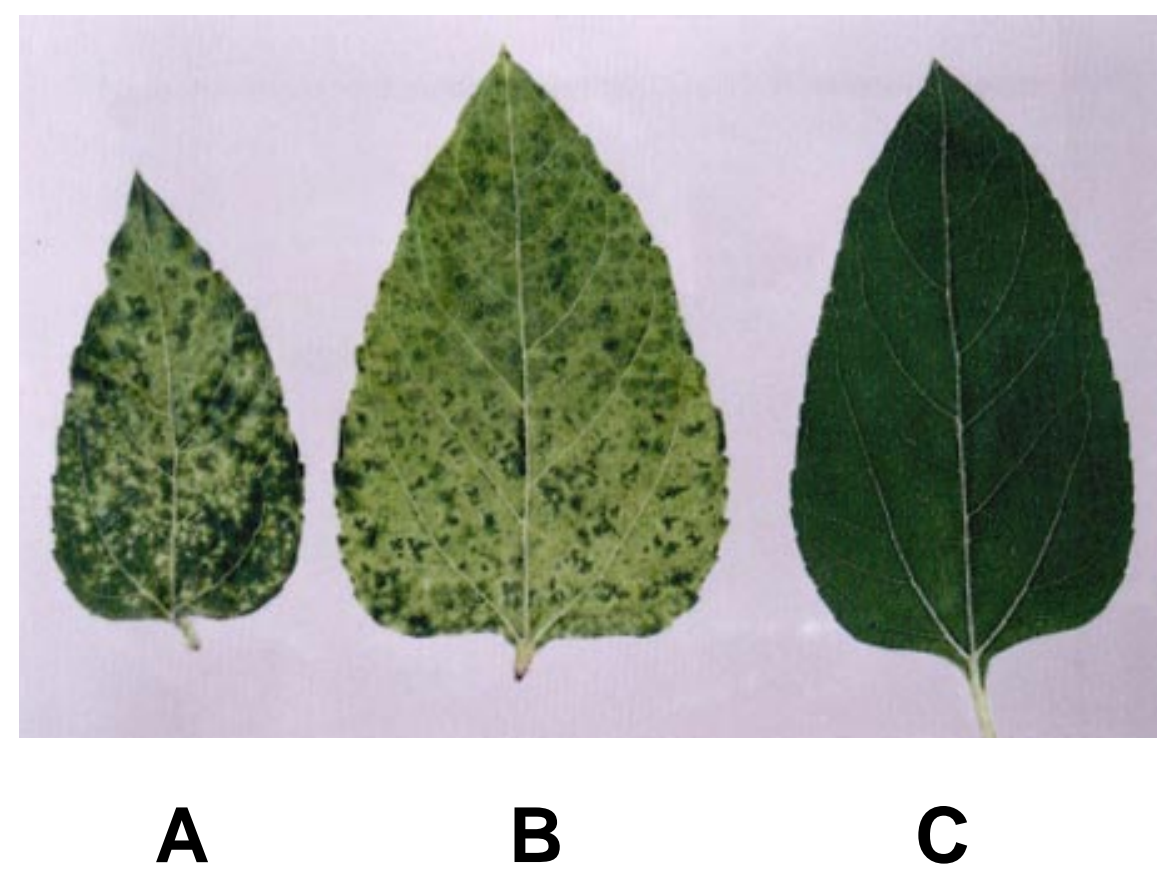

Fig. 1. Sunflower leaves showing symptoms of chlorotic mottling infection: (A) early stage of infection in a developing leaf, (B) later stage of infection in a developed leaf, and (C) healthy control. for $15 \mathrm{~min}$. The supernatant was emulsified with $1.5 \%$ Triton $\mathrm{X}-100$ by stirring the mixture for $30 \mathrm{~min}$. The emulsion was centrifuged in a TFT 5538 Centrikon rotor (Kontron Instruments, Milan, Italy) at $113,700 \times g$ for $1 \mathrm{~h}$, and the pellet was resuspended in $1.5 \mathrm{ml}$ of $0.5 \mathrm{M}$ borate buffer, $\mathrm{pH} 8$, containing $0.01 \mathrm{M}$ EDTA. The suspension was clarified by centrifugation in a Beckman JA-20 rotor at 7,800 $\times$ $g$ for $15 \mathrm{~min}$, and the virus was concentrated by centrifuging in a TFT 6513 Centrikon rotor at $110,000 \times g$ for $1 \mathrm{~h}$. The resulting pellet was resuspended in $5 \mathrm{ml}$ of extraction buffer and mixed with $1.95 \mathrm{~g}$ of $\mathrm{CsCl}_{2}$ followed by rate equilibrium centrifugation in a Sorvall TV 865 rotor at $245,700 \times g$ for $4 \mathrm{~h}$. Virus bands were visualized by vertical light, collected with a syringe, diluted 10 times with $0.05 \mathrm{M}$ borate buffer, $\mathrm{pH} 8$, containing $1 \mathrm{mM}$ EDTA (vol/vol), centrifuged in a TFT 6513 Centrikon rotor at $110,00 \times g$ for $1 \mathrm{~h}$, and resuspended in Hepes saline buffer (20 $\mathrm{mM}$ Hepes, $0.15 \mathrm{M} \mathrm{NaCl}, \mathrm{pH}$ 7.3). Virus purity and concentration were estimated by spectrophotometry (11).

Antiserum source. An antiserum was prepared by injecting a rabbit with $400 \mu \mathrm{g}$ of purified virions suspended in $500 \mu \mathrm{l}$ of Hepes saline buffer and emulsified with an equal volume of Freund's complete adjuvant. After 21 days, a booster injection was given. Blood was collected 7, 21, and 45 days after the first immunization, and the sera were separated. A monoclonal antibody common to aphid-transmitted potyviruses (Agdia PSA 272) and polyclonal antisera to BiMoV (ATCC 165-PVAS), BiMV (E. Kitajima, São Paulo, Brazil), potato virus $\mathrm{Y}$ (PVY), and maize dwarf mosaic virus (MDMV) (IFFIVE-INTA, Argentina) were used for serological tests.

Determination of the molecular weight of the capsid protein. Ten $\mu$ of

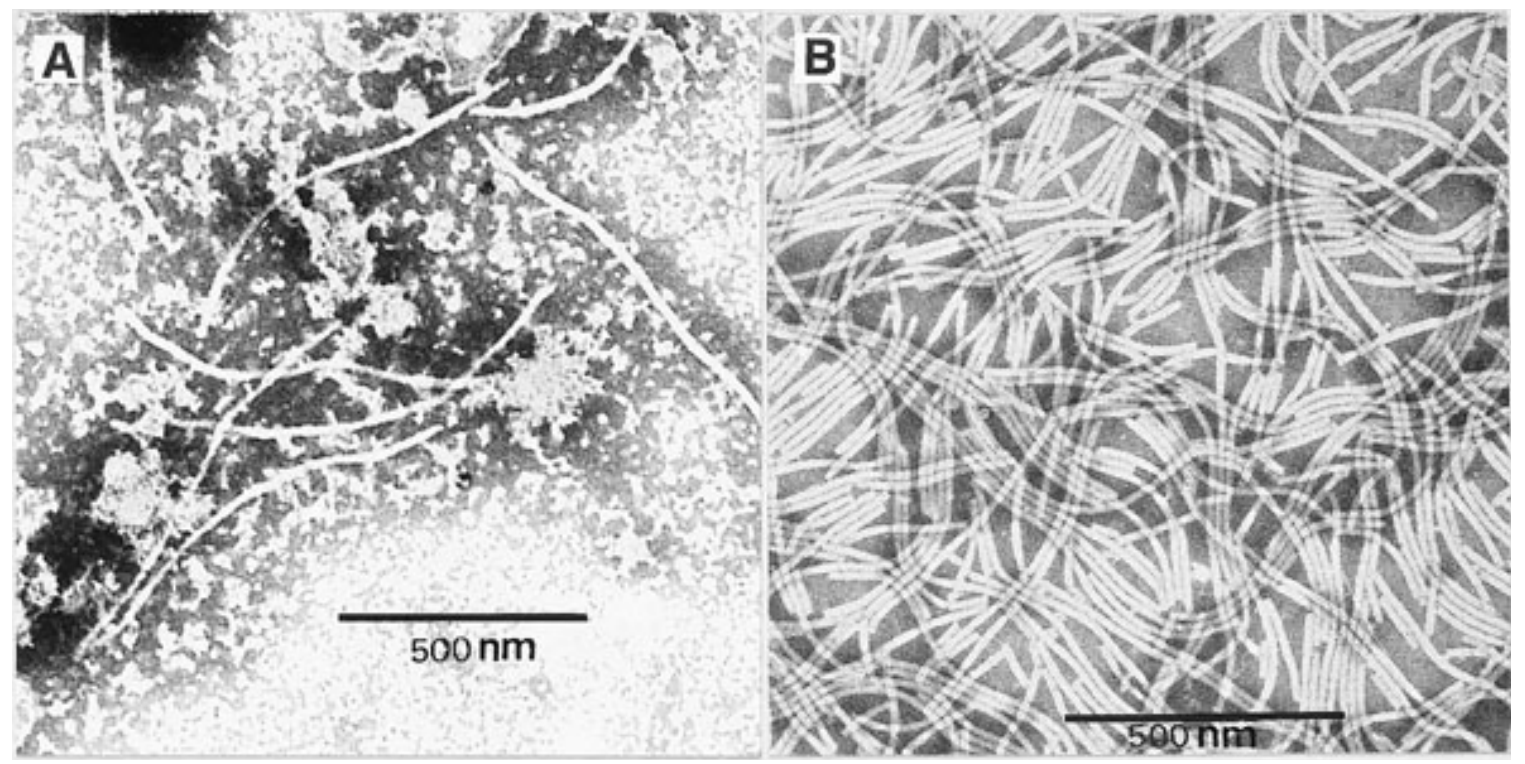

Fig. 2. (A) Electron micrographs of virus particles in leaf dips from a sunflower infected and (B) partially purified preparation. 


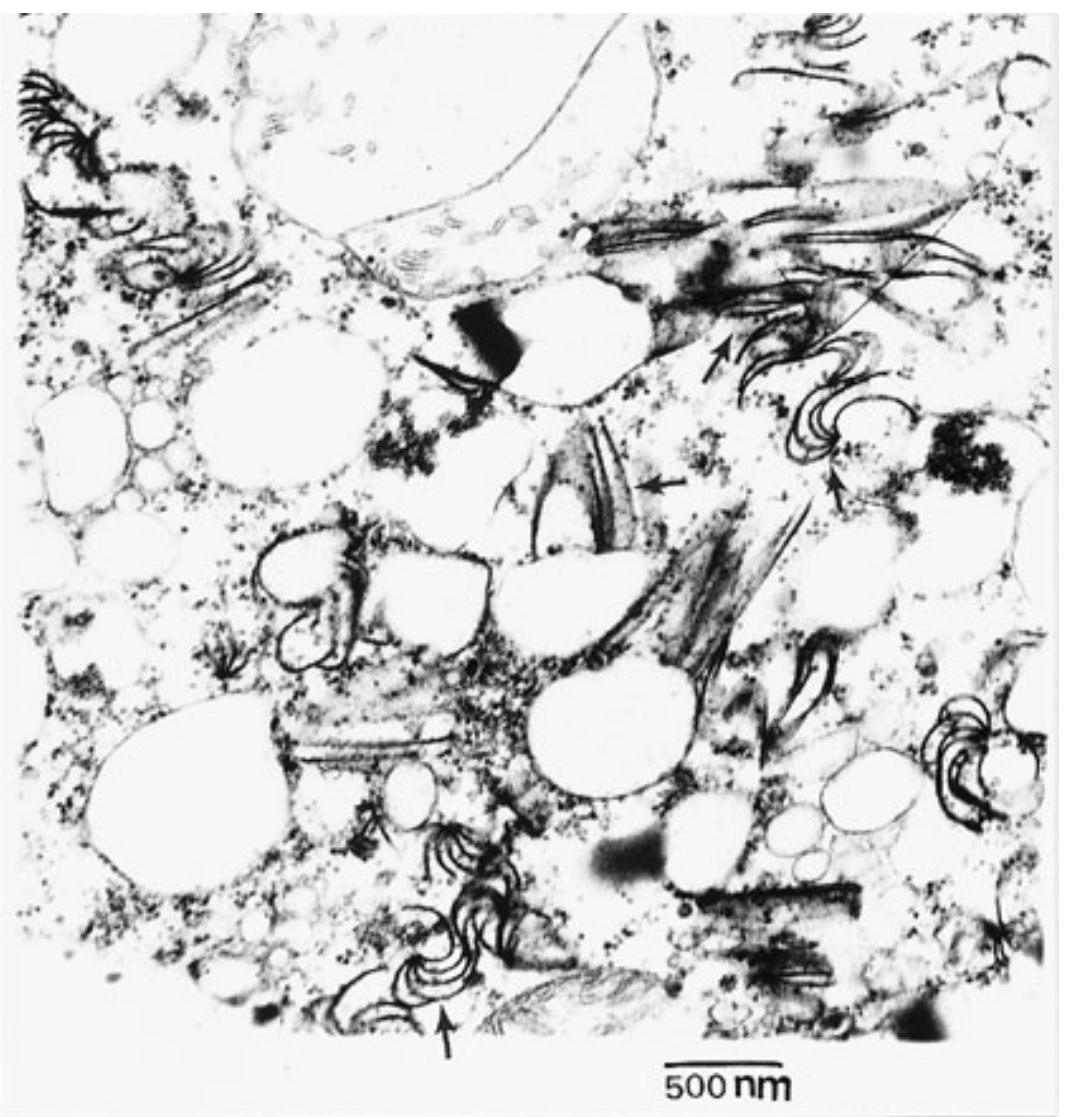

Fig. 3. Ultrathin section of sunflower leaf infected with sunflower virus showing cytoplasmic laminar aggregates and pinwheel inclusions.

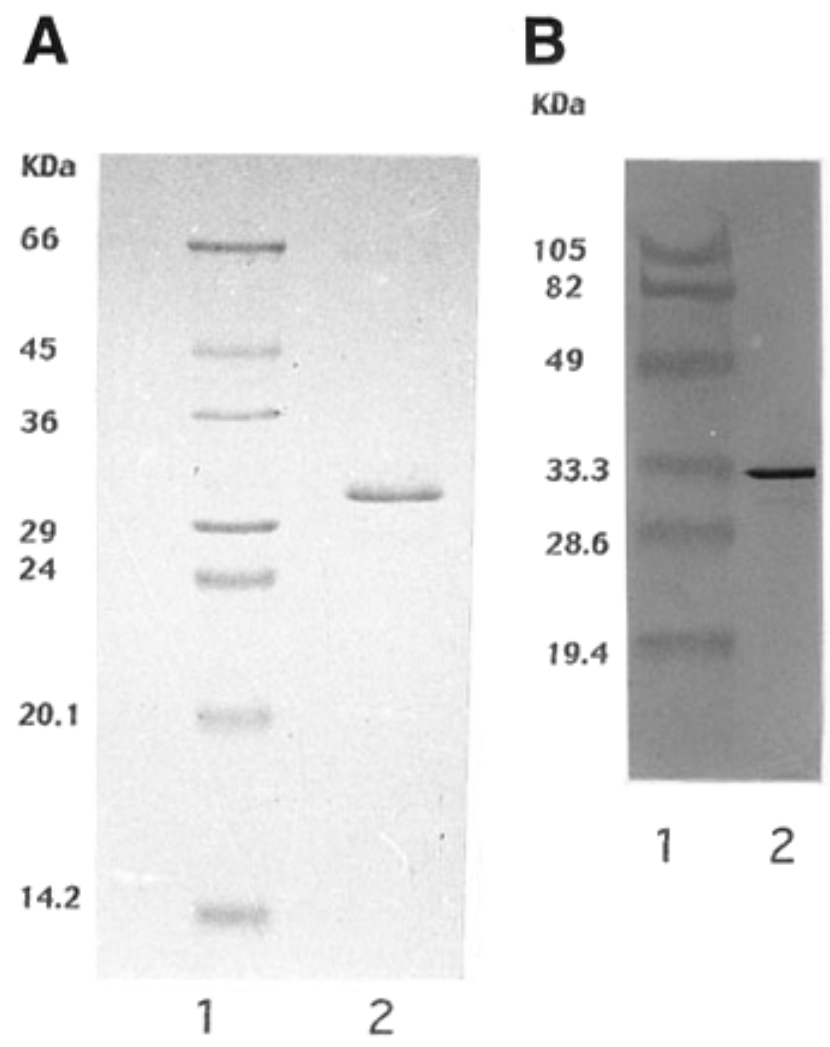

Fig. 4. (A) Electrophoresis of sunflower virus coat protein on 5 to $15 \%$ discontinuous sodium dodecyl sulfate-polyacrylamide gel electrophoresis. Lane 1 contains low molecular weight marker proteins. Lane 2 contained sunflower virus capsid protein. (B) Western blot of sunflower virus capsid protein probed with its homologous polyclonal antiserum (early bleeding). Lane 1 contains prestained low molecular weight marker proteins. Lane 2 contains sunflower virus capsid protein. purified virus were mixed with $20 \mu \mathrm{l}$ of protein sample buffer (7) and heated at $100^{\circ} \mathrm{C}$ for $5 \mathrm{~min}$. Low molecular weight marker proteins (Sigma, St. Louis, MO) were similarly prepared. Samples were subject to sodium dodecyl sulfate-polyacrylamide gel electrophoresis (SDSPAGE) in a 5 to $15 \%$ discontinuous gel (7) with a Micro Slab Gel Electrophoresis unit (Marysol, Tokyo, Japan). The molecular weight of the capsid protein was estimated using regression analysis.

Serological tests. Western blots. The purified virus capsid protein $(1 \mu \mathrm{g})$ and prestained low molecular weight marker proteins (PSLMWM, Bio-Rad Laboratories, Hercules, CA) were subject to SDSPAGE as above in a Mini-protean II Dual Slab Cell (Bio-Rad Laboratories) and then transferred to nitrocellulose (NC) membranes with a Mini trans-blot electrophoretic transfer cell (Bio-Rad Laboratories). The membrane was treated as by Lenardon et al. (9) and then probed with antiserum against sunflower virus at a 1:5,000 dilution. Leaves infected with sunflower virus, BiMoV (ATCC), and healthy sunflower leaves were ground in TBS $(0.02 \mathrm{M}$ Tris, $0.15 \mathrm{M} \mathrm{NaCl}, 0.02 \% \mathrm{NaN}_{3}, \mathrm{pH} 7.5,0.05 \%$ Tween 20, and $0.01 \mathrm{M}$ diethyldithiocarbamic acid) $1: 10(\mathrm{wt} / \mathrm{vol})$. The slurry was centrifuged at $9,000 \times g$ for $5 \mathrm{~min}$, and the supernatant was saved. Twenty $\mu$ of each suspension and PSLMWM were treated as aforementioned, and the blot was developed with a monoclonal antibody common to aphid-transmitted potyviruses diluted 1:200.

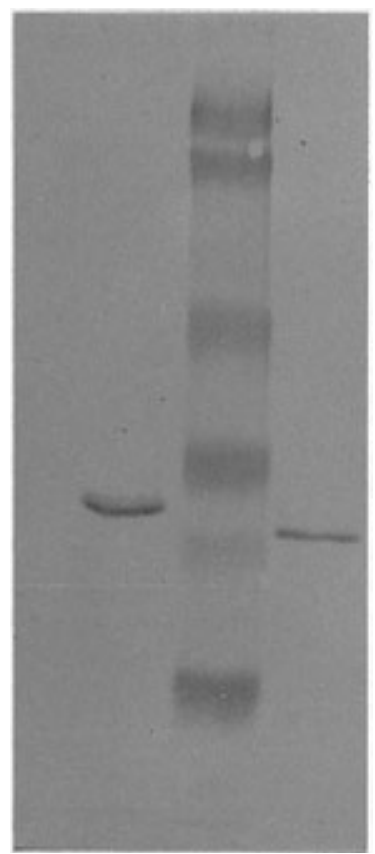

Fig. 5. Western blot of Bidens mottle potyvirus (BiMoV) and sunflower virus leaf extract probed with a monoclonal antibody to aphidtransmitted potyvirus. Lane 1 contained BiMoV leaf extract. Lane 2 contained prestained low molecular weight markers (same as Figure 4B). Lane 3 contained sunflower virus leaf extract. 
Dot blot immunoassay. Crude extracts from infected and healthy leaves were prepared as for Western blot, but the tissue to buffer ratio was $1: 15$ (wt/vol). Thirty $\mu \mathrm{l}$ of each sample was blotted onto NC membranes using home-made protein blotting equipment and treated as in Lenardon et al. (9).

Relation of sunflower virus with other potyviruses. Sap from leaves of $Z$. mays infected with MDMV, N. occidentalis infected with PVY, sunflower virus, and the respective healthy controls were blotted onto NC membranes. They were then probed with SuV-As, MDMV-As, and PVY-As diluted 1:5,000, 1:10,000, and 1:32,000, respectively.

Relationship of SuV-As to different geographical isolates of the virus. Sunflower virus samples from Paraná, Venado Tuerto, and Río Cuarto isolates, healthy and buffer controls, were blotted onto NC membranes and tested against the $\mathrm{SuV}-\mathrm{As}$ (diluted 1:5,000).

Relationship of sunflower virus to BiMoV and BiMV. NC membranes containing samples from healthy and infected sunflower, BiMoV, and buffer were tested against $\mathrm{SuV}$-As from bleeding days 21 and 45, and antisera against BiMoV and BiMV (diluted 1:5,000). Antigen for BiMV was not available.

\section{RESULTS}

Mechanical transmission and host range. The sunflower virus was efficiently transmitted to sunflower by rub-inoculation (73 to $100 \%)$. Chlorotic mottling appeared 7 to 10 days after inoculation; it later coalesced and became systemic (Fig. 1). Yellow blotches developed on the lamina, followed by distortion and stunting of the plant. The virus was transmitted to plant members from Amaranthaceae, Asteraceae, Chenopodiaceae, and Solanaceae (Table 1). Back-inoculation onto sunflower from susceptible and nonsusceptible hosts showed that only susceptibles reproduced the disease. Leaf dip electron microscopy revealed potyvirus-like particles in all susceptible hosts.

Aphid and seed transmission. The sunflower virus was experimentally transmitted by the aphid $M$. persicae in a nonpersistent manner with a 31 to $49 \%$ efficiency. None of 406 plants tested for seed transmission showed viruslike symptoms 2 months after planting.

Electron microscopy. Flexuous rodshaped particles approximately $17 \times 770$ $\mathrm{nm}$ were observed on negatively stained leaf dips of infected sunflowers (Fig. 2A). Cytoplasmic laminar aggregates and pinwheel inclusions characteristic of potyvirus-infected tissue were observed in ultrathin sections of infected sunflower leaf tissue (Fig. 3).

Virus purification. Partially purified virus preparations had a $260 / 280 \mathrm{~nm}$ ratio of $1.31: 1.40$, and concentration ranged between 4.5 and $11.5 \mu \mathrm{g}$ of virus per $\mathrm{g}$ of green tissue. Electron microscope examination of negatively stained samples showed flexuous rods (Fig. 2B).

Capsid protein and Western blot. A single protein band with an estimated molecular weight of $33 \mathrm{kDa}$ was observed in SDS-PAGE (Fig. 4A). A single band was also observed when a membrane containing the sunflower virus capsid protein was probed with its homologous antiserum (Fig. 4B) and with a monoclonal antibody to the potyvirus family, but the sunflower virus capsid protein was smaller than $\mathrm{Bi}$ MoV (Fig. 5).

Dot blot immunoassay. MDMV, PVY, and sunflower virus samples reacted only with their homologous antisera (Fig. 6A). None of the antisera tested reacted against healthy samples or buffer controls (Fig.

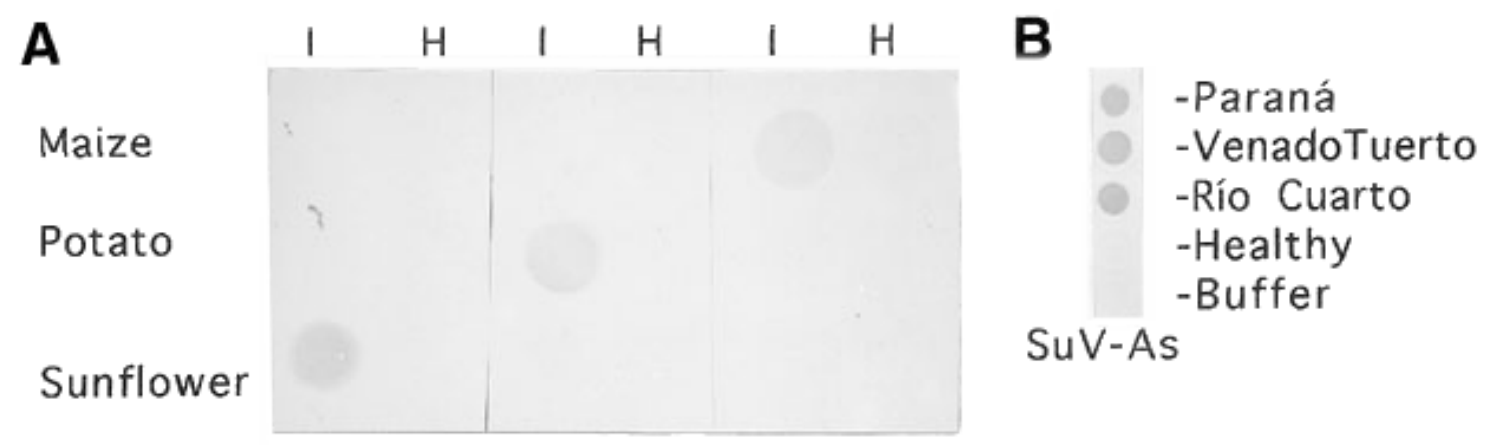

SuV-As. PVY As. MDMV As.

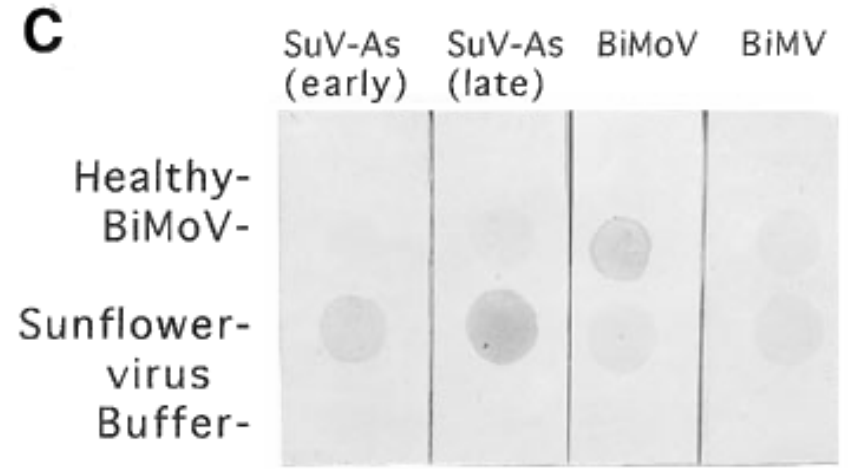

Fig. 6. Dot blot immunoassays: (A) membranes containing infecting (I) or healthy (H) leaf tissues: maize dwarf mosaic potyvirus (MDMV) (maize), potato virus Y (PVY) (potato), and sunflower virus (SuV) probed with SuV, PVY, and MDMV antisera (As), respectively; (B) membrane containing Paraná, Venado Tuerto, and Río Cuarto SuV isolates, and healthy and buffer control probed with SuV-As; and (C) membranes containing healthy sunflower, Bidens mottle potyvirus (BiMoV), SuV, and buffer control probed with SuV-As (early and late bleedings), BiMoV, and Bidens mosaic virus (BiMV) antisera. 
$6 \mathrm{~A}-\mathrm{C})$. The three geographical isolates of sunflower virus (Paraná, Venado Tuerto, and Río Cuarto) reacted similarly to the SuV-As (Fig. 6B). The early-bleeding SuV-As specifically detected the homologous antigen and weakly reacted against BiMoV. The late-bleeding SuV-As reacted with its homologous antigen as well as with BiMoV. In turn, BiMoV and BiMV antisera reacted with sunflower virus and BiMoV, respectively (Fig. 6C).

\section{DISCUSSION}

In Argentina, sunflower is one of the most important oil crops. It is processed as oil and subproducts and exported. This study showed that sunflower plants in several areas, including the provinces of Entre Rios, Santa Fe, and Córdoba, are infected by a virus that causes stunting and chlorotic mottling. Yield losses associated with this disease are relatively limited, but they could be important when infections occur at an early stage of plant development.

The host range for this virus appears to be narrow, since only nine of 42 putative hosts were infected. Symptoms induced by this virus were similar to those of BiMoV and BiMV on $H$. annuus, Bidens spp., $C$. amaranthicolor, $C$. quinoa, and $Z$. elegans $(2,3,5,12)$. However, it did not infect $N$. clevelandii and $L$. sativa, which are hosts for BiMoV and BiMV $(2,12)$, nor P. sativum, reported as host for BiMV (12). Nevertheless, these differences in host range could be due to the cultivars used in this and the previous studies $(2,12)$.
Virus morphology and cytoplasmic inclusions are similar to those caused by other potyviruses infecting sunflower (4), but in this case, no bundles were seen in the cytoplasm of infected cells. The size of the capsid protein of this virus is within the range reported for most potyviruses (13); it is similar to BiMV (12) but slightly smaller than BiMoV. Monoclonal antibodies recognized this virus as a member of the genus Potyvirus (13). Recently, preliminary studies have shown that BiMV and $\mathrm{BiMoV}$ seem to be related, since $\mathrm{Bi}$ MoV antiserum cross-reacted with BiMV isolates by dot-ELISA (12). The weak reaction with the specific early bleeding $\mathrm{SuV}$-As and BiMoV seen in this study suggests that this sunflower virus may also be related to those potyviruses.

Additional studies, including cloning and sequencing of the $3^{\prime}$ end region, are underway to further characterize this potyvirus.

\section{ACKNOWLEDGMENTS}

We thank CONICOR, INTA, and JICA for financial support. G. Dujovny holds a research fellowship from CONICOR. T. Usugi and $\mathrm{K}$. Shohara are research scientists from JICA. We thank E. Kitajima (NAP/MEPA-Department of Fitopatología, ESALQ/University of São Paulo, Brazil) for providing the antiserum to BiMV and for reviewing the manuscript, and R. Louie (USDA-ARS, Department of Plant Pathology, Ohio State University) for helpful suggestions.

\section{LITERATURE CITED}

1. Arnott, H. J., and Smith, K. M. 1967. Electron microscopy of virus-infecting sunflower leaves. J. Ultrastruct. Res. 19:173-195.

2. Christie, S. R., Edwardson, J. R., and Zettler,
F. W. 1968. Characterization and electron microscopy of a virus isolated from Bidens and Lepidium. Plant Dis. Rep. 52:763-768.

3. Costa, A. S., and Kitajima, E. W. 1966. Virus do mosaico do picão ataca o girassol. O Estado de São Paulo, São Paulo. Supl. Agríc. J. 605:12-13.

4. Edwardson, J., and Christie, R. G. 1996. Cylindrical inclusions. Fla. Agric. Exp. Stn Inst. Food Agric. Sci., Bull. 894, University of Florida, Gainesville.

5. Khun, G. B., Lin, M. T., and Costa, C. L. 1980. Transmissão, círculo de hospedeiras e sintomatologia do vírus do mosaico do picão. Fitopatol. Bras. 5:39-50.

6. Kitajima, E. W., Carvalho, A. M. B., and Costa, C. L. 1961. Morfologia do virus do mosaico do picão. Bragantia 20:503-512.

7. Laemmli, U. K. 1970. Cleavage of structural proteins during the assembly of the head of bacteriophage T4. Nature 227:680-685.

8. Lenardon, S. L. 1994. Síntomas de etiología viral en cultivos de girasol. Pages 99-103 in: Enfermedades del Girasol en la Argentina. V. R. Pereyra and A. R. Escande, eds. INTA, Balcarce, Buenos Aires, Argentina.

9. Lenardon, S. L., Gordon, D. T., and Gingery, R. E. 1993. Serological differentiation of maize dwarf mosaic potyvirus strains A, D, E, and $\mathrm{F}$ by electro-blot immunoassay. Phytopathology 83:86-91.

10. Martelli, G. P., and Russo, M. 1984. Thin sectioning to identify plant viruses. Methods Virol. 8:143-224.

11. McDaniel, L. L., and Gordon, D. T. 1989. Characterization of the oat-infecting strain of maize dwarf mosaic virus. Phytopathology 79:113-120.

12. Nagata, T., Inoué, A. K., Dusi, A. N., and Kitajima, E. W. 1995. Bidens mosaic potyvirus newly isolated from pea, its characteristics and serological relationship with other potyviruses. Fitopatol. Bras. 20:473-478.

13. Shukla, D. D., Ward, C. W., and Brunt, A. A. 1994. The Potyviridae. CAB International, Cambridge. 